\title{
The Political Heritage of Textile Districts: Shanghai and Mumbai
}

\author{
Mark W. Frazier \\ Department of Politics, The New School for Social Research, New York, United States \\ Email: frazierm@newschool.edu
}

\begin{abstract}
This article examines the evolution of mill districts in Shanghai and Mumbai across the $20^{\text {th }}$ century as cases of political heritage -in which the socio-spatial formations of factory and neighbourhood produced new meanings of citizenship for the workers in each city. Using historical materials from the textile industry in each city, government reports, housing data, and secondary sources, this article first traces the origins of Shanghai's textile industry in the $19^{\text {th }}$ century to its connections with Bombay's textile mills, then examines the emergence of working-class neighbourhoods as they acquired distinctive patterns of tenement housing, shopfronts, and street life. The main finding is that despite clear differences in the two cities in terms of religion, culture, and politics, the 'mill district' became a socio-cultural formation central to the identity and memory of generations of textile workers in Shanghai and Mumbai. A concluding section examines the similar process in each city in the $21^{\text {st }}$ century in which mill compounds and neighbourhoods were converted into high-end commercial real estate and sites for consumption and leisure.
\end{abstract}

KEYWORDS industrial heritage, political heritage textile industry, urban housing, citizenship, Mumbai history, Shanghai history

Received June 10, 2019; accepted August 15, 2019.

For much of the $20^{\text {th }}$ century, Shanghai was China's leading manufacturing centre, and the cotton textile sector was Shanghai's leading industry. The same is true for Bombay's position in the Indian economy during the $20^{\text {th }}$ century-in fact, Shanghai's cotton textile industry in the 1890s owes its origin in part to Bombay's mills and port, which supplied the crucial inputs of spun as well as raw cotton. By the turn of the $21^{\text {st }}$ century, both cities had lost their cotton textile industries, along with the hundreds of thousands of jobs they provided (at their peak, about 250,000 in Bombay, and 500,000 in Shanghai). The cotton mill districts remain central to each city's identity and built heritage, with the mill compounds, the iconic brick smokestacks, and tenement housing invoking for many long-term residents the once vibrant and contentious working-class culture of the mill districts. To work in a cotton mill, to live in a mill neighbourhood, and to partake in the daily life of work, consumption, and leisure in the crowded streets and narrow lanes of the mill districts was a sign of social status and working-class prosperity attached to the vision of mid- $20^{\text {th }}$ century socialist ideology found in both cities. Earlier in the $20^{\text {th }}$ century, the leaders of nationalist movements, as well as the organizers of communist party-led mobilisations, sought out the textile workers of Bombay and Shanghai as crucial allies. The prominent place of mill districts in these two cities was no accident-their status as global textile producers arose from their origins as manufacturing centres under $19^{\text {th }}$ century British colonial capitalism, in particular the consequences of the Opium War (1839-1842). Once established as the centres of manufacturing jobs, the mill districts of Shanghai and Bombay served as the locus of political and ideological currents that swept each city: nationalism, socialism, communism, and by the late $20^{\text {th }}$ century, neoliberal visions of urban development. However, relative to other buildings and neighbourhoods associated with colonial elites and commerce, there have been only weak attempts to protect and preserve the built heritage of the mills and mill districts of Shanghai and Mumbai. To the extent that preservation discourse covers the industrial heritage, it has been centred largely on the mills and mill lands rather than the once thriving neighbourhoods surrounding the mills (Chalana 2012, 13). 
Historians of Shanghai and Bombay have extensively chronicled the lives, the workplaces, the residences, the neighbourhoods, as well as the cultures and social relations that gave the mill districts their distinctive-and at times contentious character (Chandavarkar 1994; Chandavarkar 2009; Adarkar and Menon 2004; Upadhyay 2004; Newman 1981; Morris 1965; Luo 2011; Honig 1986; Perry 1993). But the two cities and their textile sectors have rarely been compared as global crossroads. In this article, I show how the late $19^{\text {th }}$-century origins of Shanghai's textile mills derived in part from the mid-19 $9^{\text {th }}$-century boom in production by Bombay's mills. Given the obvious contrasts in religion, culture, and political institutions between the two cities, it is striking how the evolution of the textile sector as the leading employer in each city produced similar patterns in migration, residence, and debates over the political status and rights of textile workers. By the first decades of the $20^{\text {th }}$ century, if Bombay's textile mills no longer enjoyed commercial connections with Shanghai (in the form of yarn exports), what loosely connected the two cities was their position as national nodes in global currents of anti-imperialist and anti-capitalist sentiments that coalesced into competing nationalist and communist political parties. When new ruling parties governed India and China after 1947 and 1949, they approached the two cities, which had become symbols of imperialist domination, with some caution. Both governments imposed wide-ranging restrictions on the cotton textile industry and more generally steered investment away from the sector. The mill workers in each city achieved substantial social and political status and agency in 1950s and 1960s, owing in large part to their attaining membership in the ranks of the urban proletariat at a time when official ideology promoted socialism. By the late $20^{\text {th }}$ century, the direction of influence flowed from Shanghai to the renamed city of Mumbai (in 1995). The 'Shanghai miracle' of infrastructure led-development and monumental office towers, including a rapid transformation from industrial to service employment in the textile sector and many other core industries, proved an irresistible model for Mumbai's civic elites.

The article is organised as follows: the first section situates the mill districts of Shanghai and Bombay geographically and historically, and connects the origins of Shanghai's cotton textile industry with Bombay's cotton boom in the latter half of the $19^{\text {th }}$ century. The section that follows traces the evolution of mill neighbourhoods as social and political formations where citizenship questions arose to prominence. A third section discusses the heyday of the mill districts in the mid- $20^{\text {th }}$ century, followed by a fourth section in which the commodification of urban land in the late $20^{\text {th }}$ century brought about the rapid demise of the sector and efforts to repurpose the mill land from production to consumption-a process known in Bombay as the transformation of 'mills to malls'.

\section{Origins and Coevolution}

Like the city itself, Shanghai's cotton textile industry arose from the efforts by Chinese entrepreneurs and officials who aspired to develop modern industry for China, and from the pursuit of expanded markets by foreign textile firms and the governments who backed them to establish operations and influence in China. By the early 1920s, massive mill compounds spanned vast stretches of waterfront in Yangshupu district along the Huangpu River, and in Zhabei and Putuo districts on land alongside Suzhou Creek. (See Figure 1 showing concentrations of textile mill employees in 1936.) It is no accident that these two mill districts were situated on the respective eastern and western borders of the International Settlement (1843-1943), the multinational sovereign territory established and largely run by the British under the rule of the Shanghai Municipal Council (SMC). What is less often chronicled in accounts of the origins of Shanghai's textile sector is the close reliance on imports from cotton mills in Bombay, in particular that of yarn and raw cotton.

The Treaty of Nanjing (1842) that established Shanghai as a treaty port prompted India-based companies involved in the export of cotton and opium to set up offices in Shanghai and Hong Kong. With the demise of the East India Company and its monopolies, the Jardine, Matheson and Company-famous for its role in the export of opium from India to China-moved to Shanghai in 1844 from Canton (Chen 2017, 39). Elias David Sassoon set up offices for David Sassoon and Sons in Hong Kong in 1843, and in Shanghai two years later (Betta 2003, 1001). The company had seven cotton mills in India, which profited from the export of yarn to Shanghai's nascent cotton textile industry. The first cotton mill (later known as Hengfeng) was built in Yangshupu in 1890, under the direction of the eminent statesman and state-led industrialiser, $\mathrm{Li}$ Hongzhang (Pearse 1929, 153-154). The opening of this and other cotton mills in Shanghai created a temporary boom for Bombay's mills. In 1885, Shanghai's textile mills imported 54,761 dan of yarn from Bombay, a figure that rose more than ten-fold to 667,333 dan by $1895^{1}$. Domestic production of yarn in China paled by comparison, with only 135,000 dan in 1895 (Chen 2017, 44). By the 


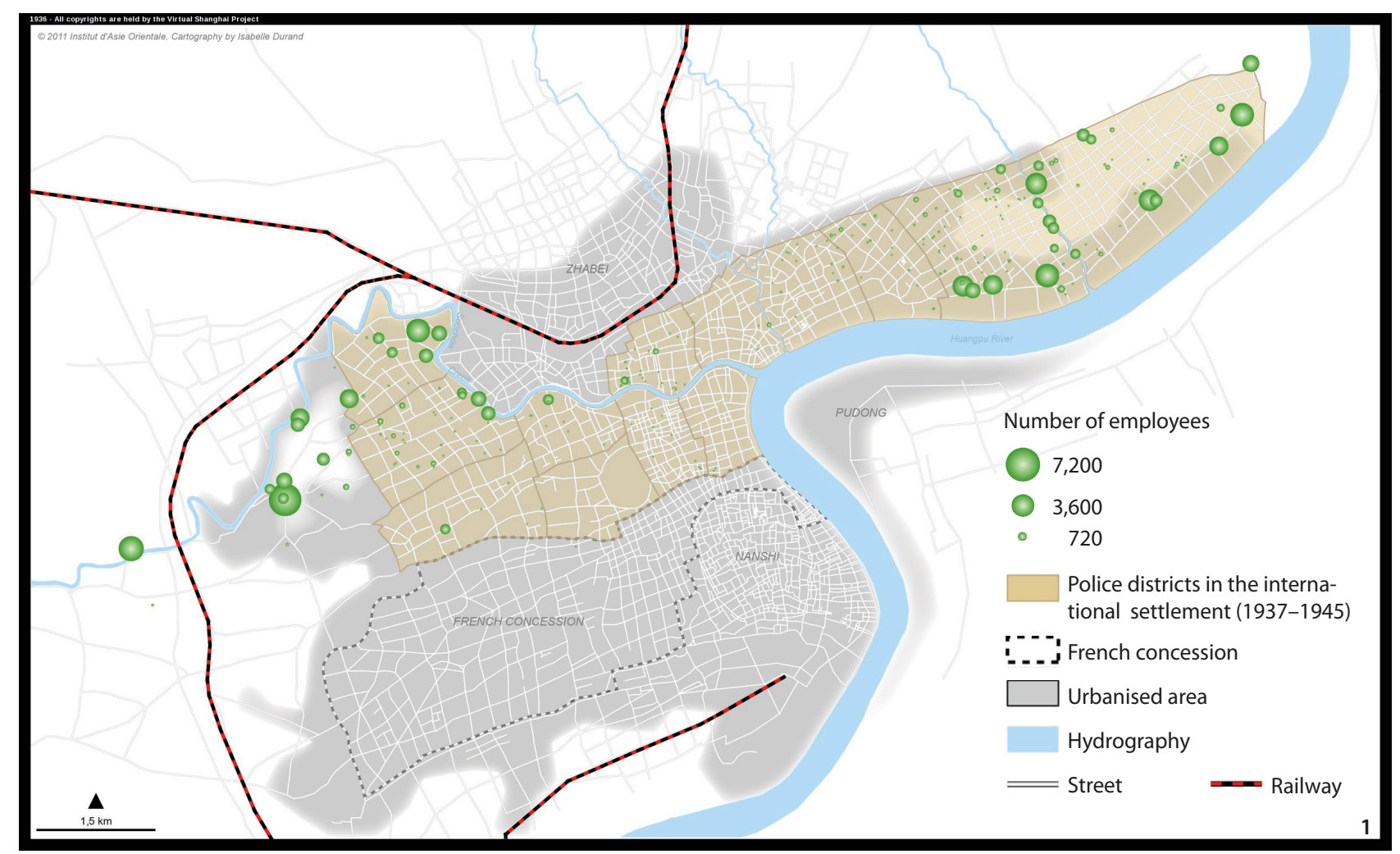

Figure 1 Concentration of Textile Workers, Shanghai, 1936 (Source: VirtualShanghai.net).

early $20^{\text {th }}$ century, Sassoon and Sons exported more yarn and cloth to Shanghai than it did opium. At least by one official count, the monetary value of Sassoon 's exports to Shanghai in 1907 was 3.63 million taels of opium, and 4.1 million taels of cotton yarn and cloth (Chen 2017, 41).

It was not only the export of yarn from Bombay that jump-started what would become Shanghai's most important industry by the first decade of the $20^{\text {th }}$ century. Many of the India- and Bombay-based companies involved in the China trade-Jardine, Matheson and Company, David Sassoon and Sons, among others, poured profits from their trade in opium and cotton into lucrative real estate investments in Shanghai's International Settlement. It was in 1895, at the peak of Bombay's yarn exports to Shanghai, that the International Settlement authorities resolved to engineer an embankment near the mud-flats of the Huangpu River to keep the silt away from the buildings and residences. It would be an exaggeration to say that Bombay's cotton mills made possible the construction of Shanghai's Bund, but the investment capital from banking, finance, and commerce that engineered the construction of the iconic architectural landmarks on the Bund derived from the India-China trading companies such as Jardine, Matheson and the Sassoons. The building of Sassoon House (later renamed Peace Hotel), completed in
1929, was the vision of Victor Sassoon, a scion of the Sassoon family who famously departed from Bombay in 1931 and sought out what he thought would be more favorable business opportunities in Shanghai.

The year 1895 was pivotal in the history of Shanghai and its cotton mills for another reason. The Treaty of Shimonoseki following the Sino-Japanese War (1894-1895) permitted foreign companies to build factories in China, and in that year Jardine, Matheson started the massive Ewo (Yihe in Mandarin) Cotton Mill which would eventually operate over 72,000 spindles (compared to the 2025,000 spindles found in most mills) (Pearse 1929, 155). (See Figure 2, showing another Jardine, Matheson/Ewo owned mill, the Yangtzepoo [Yangshupu] Mill in Yangshup district. The Yangtzepoo mill had 55,632 spindles in 1914. Pearse 1929, 155)

Japanese textile firms followed suit and constructed mills in the western reaches of the International Settlement, known locally as Caojiadu (Figure 1). The Naigai Wata Kaisha (Neiwai in Mandarin) company operated ten mills by the early 1920s, each employing several thousand mill hands. Chinese domestic capitalists also turned their investments into cotton textiles in Shanghai, including first and foremost the Rong family based in nearby Wuxi in Jiangsu province. The Rongs, who had owned 
Figure 2 Yangtzepoo (Yangshupu) Mill, c. 1920s (Source: VirtualShanghai.net).

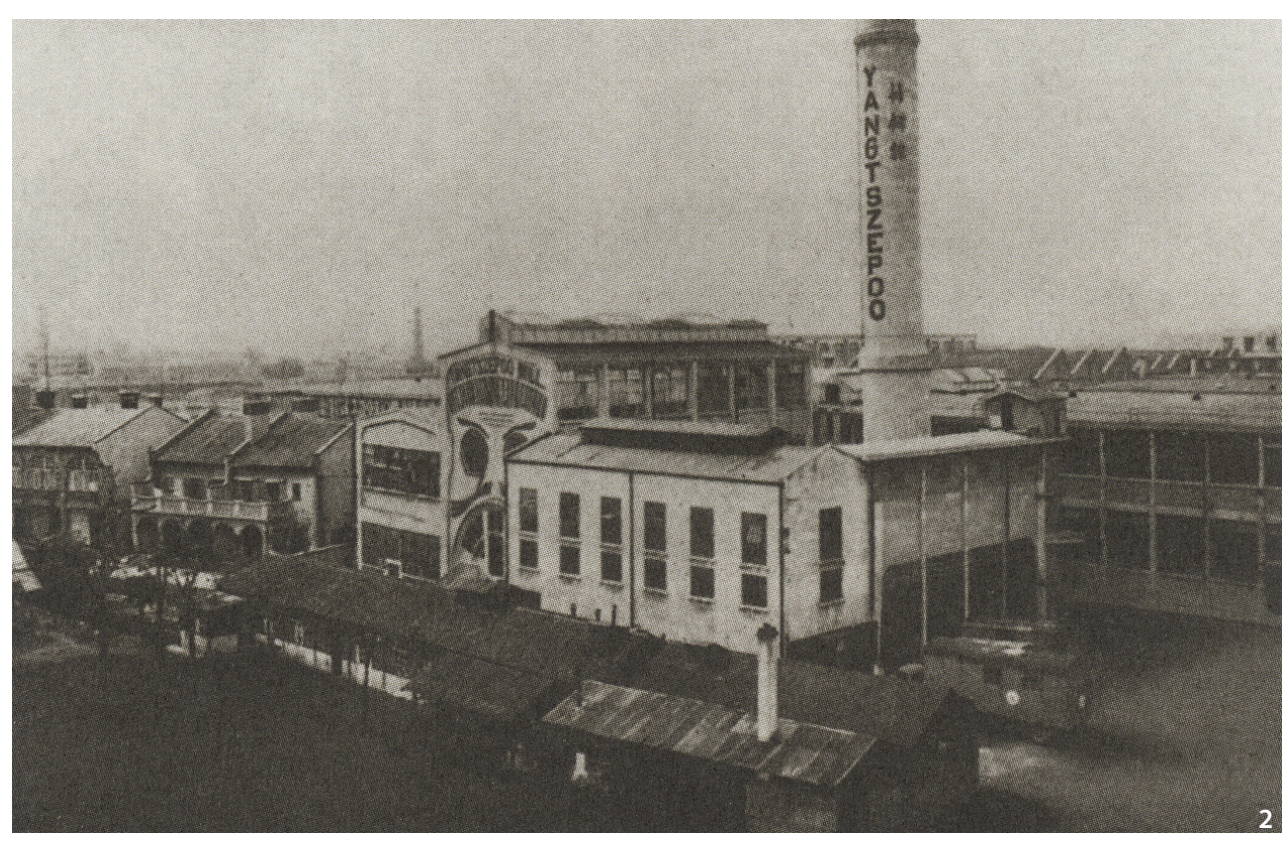

flour mills, built and operated four cotton mills under the Shenxin Corporation between 1896 and 1916. Shanghai's status as a global centre for the production of textiles was cemented following the First World War, when profits boomed (Pearse 1929, 154). With these advances in textile production in Shanghai, the booming exports of yarn once enjoyed by Bombay's mills in the late $19^{\text {th }}$ century quickly declined (Rutnagur, 1927, 69). In facing competition in yarn production from Japanese and Chinese mills based in Shanghai, Bombay mills turned largely into weaving operations, for the production of cloth. Still, one could argue that the Bombay mills with their exports of yarn to Shanghai, contributed directly to the development of cotton textiles in Shanghai.

Bombay's textile mill development was also the result of geopolitical forces that converged in the 1850 s and 1860 s. It was no coincidence that the opening of the Great Indian Peninsular Railway (1853) and the Bombay, Baroda and Central India Railway (1856), both headquartered in Bombay, occurred during the same years that the first cotton mills were built in the city. Prominent mercantile communities, especially from the Parsi community, supplied the capital for the mills, which the railways connected to the cotton-growing regions of western and central India (Figure 3). It was not long after Bombay's first four cotton mills were up and running that the American Civil War broke out, and with British mills cut off from the supply of cotton from the American South, Indian exports of raw cotton through Bombay's port boomed. Just as cotton and opium exports from Indian-based companies in the China trade helped to finance the building of Shanghai's iconic building on the Bund, the exports of cotton to Britain during the 1860s helped finance the subsequent building of the landmark architecture of Bombay: Victoria Terminus, the Bombay Municipal Corporation, the Rajabai Clock Tower, and other Victorian landmarks in South Bombay. Despite a brief crash after the resumption of cotton exports from the United States after 1865, Bombay acceded to its position as a global 'cottonopolis' for much of the late 19th and early 20th centuries (Dossal $2010,218)$. The number of cotton mills rose from 28 in 1875 (752,000 spindles) to a peak of 82 mills (3.4 million spindles) in 1925 (Chandavarkar 1994, 250). Entrepreneurs including the Tata family and David Sassoon (which set up the Sassoon Spinning and Weaving Mills in 1874) poured investment capital into the production of yarn and cloth (Adarkar and Menon 2004, 92).

As distinct from the mill compounds, the spatial formations of the mill districts of Bombay and Shanghaithose whose built heritage remains central to the identity of each city today-took form more gradually. The districts as identifiable neighborhoods with distinctive patterns of residency, street life, and folkways emerged over a decade or two: the 1870s-1880s in Bombay and the 1910s-1920s in Shanghai. Despite this time lag, the respective mill districts of Bombay and Shanghai possessed the shared traits that reflected the manner in which the textile industry attracted rural migrants from surrounding hinterlands. With housing far out of reach and jobs limited, the rural migrants arrived in Shanghai and Bombay through the networks of labor recruiters who brought them to work in the mills and arranged housing in simple tenements or even rented 


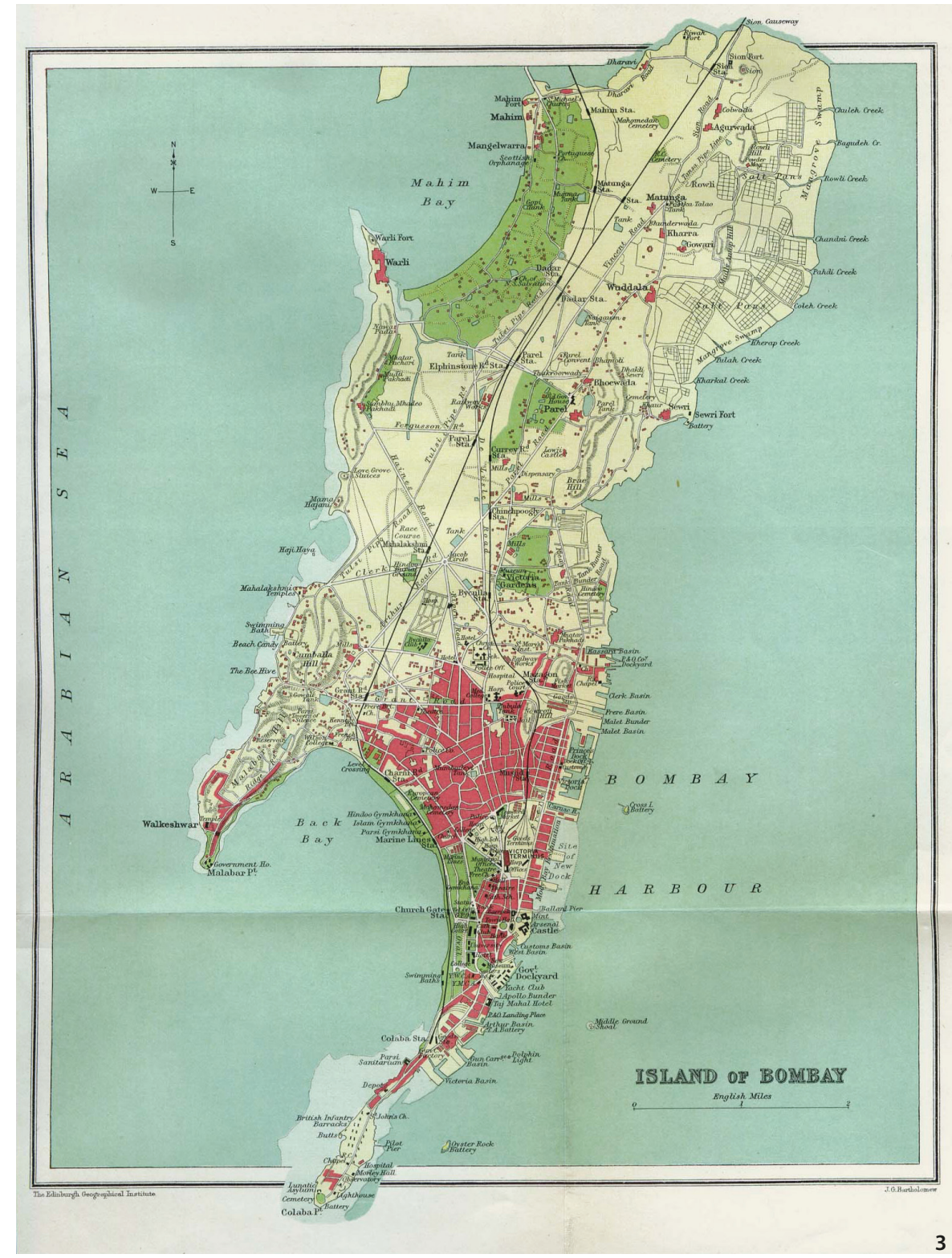

Figure 3 Map of Bombay/Mumbai, 1909. Mill districts are located in the central part of the map, on either side of the land where the two railway lines ran closely parallel to each other. (Source: The Gazetteer of Bombay City and Island, Volume 1, 1909. Map author: J. G. Bartholomew, The Edinburgh Geographical Institute). shacks. In a sense the mill districts were akin to urban frontier zones of the sort that James Farrer (2019) highlights in his discussion of bar streets of $20^{\text {th }}$ century Shanghai and Tokyo in this special issue, places of boundary crossing and ambiguous sovereignty (in the case of the International Settlement and Chinese-administered territory) wherein the organic generation of informal housing and markets gave the mill districts a gritty character in the eyes of the urban populace. While there were less desirable occupations in the cities and in the mill districts-hauling carts, collecting night soil, and various illegal 'service' occupations-working in cotton mills certainly did not accord one status as a citizen of either city, meaning entitlement to various public services, not to mention respect when encountered in the streets, markets, and tramways of the central city.
Within the mill district, looming brick smokestacks marked the location of each mill, and walls enclosed the mill compounds. The streets and lanes around the mills filled with workers, the vast majority of whom walked to and from the workplace. Around the mills, dense lanes of commerce arose to provide food and provisions, as well as leisure and cultural pursuits. In Bombay, the districts of Parel, Tardeo, Byculla, and Lalbaug were known as 'Girangaon', or 'village of mills' in Marathi. Located in the central part of the island, Girangaon was once home to 53 mills and an estimated population of 1.3 million (Adarkar and Menon 2004, 4). One survey from 1925 reported the finding that 90 percent of millworkers lived within 15 minute-walk from their workplace (Chandavarkar 1994, 169). Most lived in the iconic tenement housing, the 

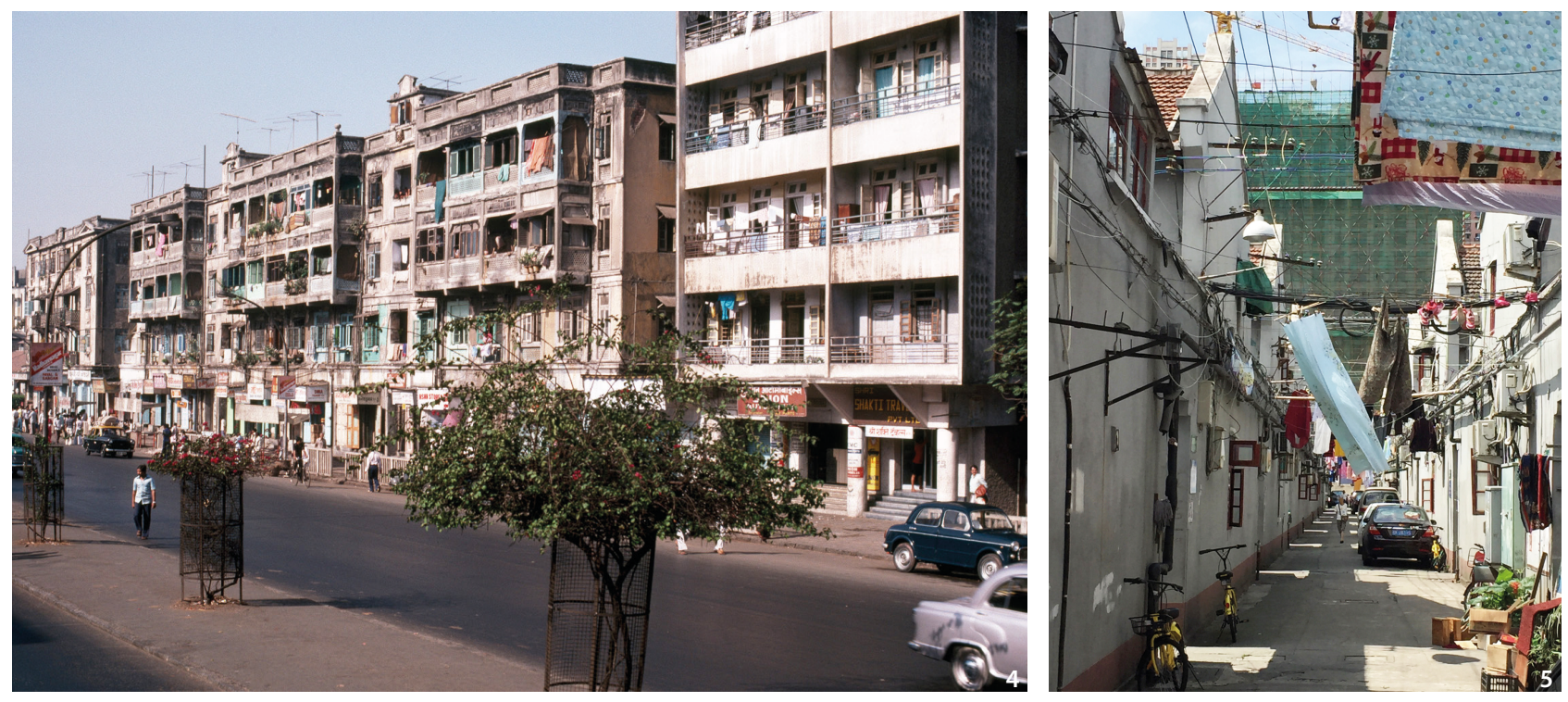

Figure 4 Chawls in Parel district, Mumbai, 1983 (Source: Aga Khan Visual Archive, Massachusetts Institute of Technology Libraries, photo by Shubhankar Sanyal).

Figure 5 Shanghai lane-alley (lilong) style workers' housing, adjacent site of former Number 19 Cotton Mill, Yangpu District, 2017 (Source: the author).

chawl. These were packed tenement housing forms build into spaces near the mills and against streets, as two- or sometimes three-storied timber frame buildings with rooms (usually only $100 \mathrm{ft}^{2}$ ) arranged off a corridor with verandahs offering the scarce resource of natural lighting (Figure 4). As landlords added floors or additional chawls next to one another, the lack of open space closed off ventilation and drainage (Hazareesingh 2007, 45-46; Chandavarkar 2009, 134-135). What Chandavarkar said of Bombay's mill district was true also of Shanghai: 'The physical structure of the working-class neighbourhoods ensured that the distinction between private and public space was sometimes worn to the point of obliteration' (Chandavarkar 2009, 134).

In Shanghai's western and eastern textile districts, Japanese-owned mills by the 1920s provided housing for some mill workers, charging rent deducted from wages (Luo 2011, 136). But the majority of mill workers lived in private rental housing or built their own shelters on tracts of empty land along Suzhou Creek. In the Gaolangqiao mill district of Yangpu, the first worker housing built by Chinese owned firms appeared in the 1920s, imitating the two-story brick-and-wood beam construction with tiled roofing found in the older style of lilong housing dating from the late $19^{\text {th }}$ century, though they were much simpler in the construction and lacked features such as courtyards and outer walls (Luo 2011, 137-138). One can still find remnants of the 1920s and 1930s worker housing in pockets of southern Yangpu-perhaps most prominently in the neighbourhood that is the former site of the Number Nineteen Cotton Mill (Figure 5). Now in their 70s and 80 s, these elderly residents and former mill workers who came to Shanghai as children in the 1930s and 1940s commonly sublease their dwellings (which they still lease for a nominal rent as public rental housing) to $21^{\text {st }}$ century migrants to Shanghai.

In Shanghai and in Bombay, and commonly in most other cities where cotton textile production was once a booming industry, the labour mill workforce was made up of migrants from impoverished rural areas in the surrounding region. Bombay's textile workers came from the Konkan region along the coast, and later from the towns connected by railway with the interior (today's western region of Maharashtra State). The mill workforce grew from about 6,600 workers in 1865 to 100,000 workers in 1892 (Adarkar and Menon 2004, 92). While Bombay's textile workforce was predominately male, Shanghai's mill workers followed a pattern in which largely female recruits were brought from rural villages to work in the large-scale spinning rooms. These workers arrived in Shanghai often through labour contractors who recruited them from impoverished rural towns and villages north of the Yangzi River, the region known as 'Subei' (in reference to northern Jiangsu) (Honig 1986). Subei migrants (women who worked in cotton mills, men who worked in what were deemed the lowliest occupations, such as coolies and night soil collectors) encountered numerous forms of discrimination and exclusion by self-styled 
Shanghai 'natives' (though they too would have migrated to Shanghai, but from areas south of the Yangzi River). For reasons possibly relating to labour legislation passed in Bombay in 1891, which prompted employers to reduce the presence of women in the workforce, Bombay's textile workers remained comprised largely of men, while Shanghai's mill workforce followed the more familiar pattern of gendered labour in which women engaged in the production of yarn especially. Men were more commonly found in weaving sheds and in mechanical and maintenance jobs in the Shanghai mills.

In the aftermath of the First World War, the mill districts came alive politically, and in the ensuing decades would acquire the reputation for political power that remains a central part of their heritage. When nationalists sought to organise city-wide protests to oppose the perpetuation of imperialist powers and their colonies at the Treaty of Versailles in 1919, they turned to the textile districts and their workers in search of allies. Shanghai saw a general strike that summer that involved textile workers at Japanese and British-owned mills. Workers in Bombay were less aligned with nationalist figures like Mohandas Gandhi, but they proved receptive to organisational efforts by Communist Party leaders in the city. Throughout the 1920s, textile workers in both cities went on strike to demand better wages and working conditions, and in response to police violence against their fellow workers during marches and strikes. The decades from the 1920s to 1940 s saw numerous strikes and union-organising efforts. And it was often the case that success in making the connection with the workforce hinged not on making alliances within the workplace but within the mill district. The Communists in Bombay, as Chandavarkar shows, proved highly adept at this by addressing community and residential concerns as much as labour issues at the workplace. Studies of textile workers in Bombay and Shanghai clearly demonstrate that divisions along the lines of gender, caste, native-place, religious community, among others, did not recede as the workforce grew in political importance over these decades (Perry 1993, Honig 1986, Chandavarkar 2009; Adarkar and Menon 2004).

Yarn exports from Bombay mills gave rise to Shanghai's textile industry, but the broader context for the creation of each city's mill districts was geopolitical in nature-a new phase of British imperialism in which 'free traders' supplanted the East India Company and facilitated the operations of firms such as Jardine, Matheson and Sassoon and Sons. Moreover, the rise of Japan as a military and economic power in the region resulted in the first treaty for foreign direct investment in China and the concentration of Japan's leading industrial firms in Shanghai to produce cotton yarn and cloth while employing tens of thousands of Chinese workers who migrated to Shanghai from poor rural districts. In the 1920s, a confluence of global ideological currents swept each city's mill district. Since Shanghai and Bombay represented a kind of 'ground zero' of imperialist domination and capitalist penetration in their respective nations, they attracted Bolsheviks, anarchists, socialists, and nationalists, among others. The mill districts and their workers became the objects of intense interest among leaders of both nationalist, anti-imperialist movements, as well as communist party organisers. After the political transitions in 1947 and 1949, workers in the textile districts of Bombay and Shanghai, once regarded as migrant communities and facing various forms of social exclusion, gained political status as the backbone of the working class of each country's leading manufacturing centres.

\section{Political Heritage: Workers as Citizens}

During the 1950s and 1960s, Bombay and Shanghai saw their once dense connections with global flows of industrial and financial capital sharply curtailed under restrictive macroeconomic policies by the respective newly established Republic of India (1947) and the People's Republic of China (1949). More consequential was the turn to statist interventions, derived from socialist commitments of each state's leadership, to place restrictions on privatelyowned textile mills in Bombay, and to eliminate private ownership altogether in the case of Shanghai industry and commerce. Despite the very different styles with which socialism was practiced at this time in the two cities, the result was a curtailment of capital investment in the textile mills and the introduction of sector-wide controls over wages and employment. While Indian and Chinese official, commercial, and cultural delegations were frequently exchanged during the 1950s, and the Bombay branch of the India China Friendship Association (ICFA) was active in promoting bilateral trade and in hosting Chinese delegations during the 1950s (Ghosh 2017, 711-714), the direct commercial links that had existed in the $19^{\text {th }}$ and the first half of the $20^{\text {th }}$ centuries between Bombay and Shanghai declined dramatically.

During these decades, the residents of the cotton mill districts of Shanghai and Bombay enjoyed unparalleled job security, stable wages, and perhaps most centrally, citizenship that had been denied to them by municipal elites in earlier decades. In Shanghai, the military cadres who 
took up administrative positions in the city in the early 1950s were largely comprised of Subei natives, and Subei people received favourable treatment for jobs in stateowned enterprises and urban collectives (elsewhere in the lower Yangzi River Delta, Subei people remained in the informal sectors as vendors and other temporary or self-employed jobs) (Chen 2007, 21). In Bombay, migrants from Marathi-speaking areas who had migrated to work in the mills came under greater protections in labour policies. The Indian National Congress (INC) government attempted to gain the support of cotton mill workers through the Rashtriya Mill Mazdoor Sangh (RMMS), a union that in legal terms had monopoly representation powers to bargain with counterparts in the Bombay Mill-Owners Association (BMOA). The Marathi-speaking mill workers remained close to the Communist Party, but would soon assert unparalleled political power after aligning with the nativist Shiv Sena movement in the mid-1960s, over inadequate representation by either political party (though the Shiv Sena would eventually compete in electoral politics by the late 1960s) ${ }^{2}$.

Labour policies in both cities (reflecting national policy favouring urban industrial workers) created protections from the risks of unemployment and wage cuts. Even in Bombay, which retained private ownership of the mills, wage and employment measures by individual enterprises were closely regulated by labour agencies and dispute resolution tribunals that had been established in late 1930s and expanded in 1946. In Shanghai, nationalisation of privately-owned textile mills brought workers and managers under complex labour and wage allocation schemes. The new policies ensured against the risks of unemployment and wage stagnation, but they did so by separating the workforces into core sectors of permanent employees and marginalised groups of temporary workers who had far fewer protections and no guarantee of future employment pending the termination of the work period ${ }^{3}$. In both cities, the new labour policies also curtailed the power of textile worker unions to lead the workforce in making demands on ownership and taking measures to go on strike. A few large-scale strikes did sweep through the textile districts of Bombay and Shanghai in a few landmark moments between the 1950s and the 1980s, but the largest strikes were often in opposition to formal union leadership, for failing to represent workers' interests.

Despite these constraints on political action and shortcomings in union representation, the textile workers of Bombay and Shanghai achieved substantial gains in terms of urban citizenship over these decades. If urban citizenship (Holston 2008) denotes equal access to housing, public services, education and cultural facilities, then the 1950s and 1960s represented high-water marks for textile workers in the two cities. In Shanghai, the construction of 'workers' new villages' provided a showcase for the Chinese Communist Party authorities to demonstrate their commitment to the working class. Also known as the 'twenty-thousand households' project (referring to the number of worker households targeted) two of the earliest 'new village' compounds were two-story brick structures located in the textile districts of Yangpu and Putuo. As a comment from a Shanghai newspaper observed, the new housing would make for a distinct contrast with the lilong housing of the past: 'The new housing is not Shanghai lilong housing, it is the product of the new style, the new democracy period' (Luo 2011, 360). Each had ample lighting, balconies, and shared kitchens and bathrooms. Even today the reminiscences of textile district residents refer to the workers' new villages as evidence of the CCP's commitment to elevate the status of Shanghai workers. This is true despite the fact that they remained showcases, with only a fraction of mill workers and families gaining access to the new units. A considerable portion of workers remained in pre-1949 housing built nearby the mills and in concrete apartment blocks built later as part of workplace-provided housing. In Bombay, the chawls remained the nearly exclusive form of housing in the mill districts. While some had modest upgrades, efforts by the government to push mill owners to build additional housing foundered, largely because of the high cost of land on which to build new construction. But the districts continued to thrive as cultural sites, famous for communityorganised drama troupes, theatres, and gymnasia, all reflecting a Girangaon culture that both maintained the practices of villages from which the residents came and new hybridities produced from the interactions of among different regional practices. In both cities, textile mill worker families recall the period with nostalgia as a simpler time when jobs were secure and wages were sufficient to sustain livelihoods as a manufacturing worker.

At the same time, the mills districts of Shanghai and Bombay suffered from a severe lack of investment beginning in the 1950s. The Chinese Communist Party leadership in Beijing, after carrying out the nationalisation of privately-owned textile mills in Shanghai during the 1950s, diverted capital investments away from Shanghai and toward other industrial cities. In Bombay, mill owners also faced national policies that constrained the flows of investment capital and supported small-scale textile 
producers. While there was no state takeover of the mills anywhere near the scale found in China, the Bombay mill owners responded to government policies by diverting their investment capital away from the mills, into chemical and pharmaceutical industries, eventually into finance and real estate. Over the long run, the underinvestment in physical plant and machinery in each district meant that the elevated status of workers was not commensurate with the dilapidating conditions of the mills and the mill neighbourhoods, especially housing.

Nor can it be said that the textile workforces of Bombay and Shanghai at this time uniformly enjoyed job security and stable wages. As noted above, the workforce was starkly divided between full-time and temporary workers-even in Shanghai, which witnessed in the early 1960s various policies to permit mill managers to obtain the labour of temporary workers and apprentices, who could be paid at far lower wage rates without the benefits accorded full-time workers. In Bombay, labour legislation dating from 1938 and revised in 1946 created a powerful union representation for Bombay's mill workers, but also divided work tasks into unionised and non-union positions, which mill owners could exploit ${ }^{4}$. Tensions arising from these intra-workforce divisions based on job status erupted in both cities as part of broader political currents in the 1960s: temporary workers in Shanghai mobilised to present grievances during the early phases of the Cultural Revolution in 1966-1967, as did underemployed mill workers in Bombay (as well as many full-time workers) flock to the nativist Shiv Sena in 1966 (Frazier 2019, 170-191).

By the 1980s, the cotton mill districts in both cities had unintentionally preserved the built environment of a halfcentury earlier, when most of the compounds and neighbourhood housing was constructed. One exception was the enterprise reforms in Shanghai that allowed factory managers to retain profits for use within the enterprise, resulting in a wave of employer-provided housing construction alongside the older housing from decades past. In both cities, the emergence of rival producers-the smallscale power looms in Bombay's suburbs, and the township and village enterprises in the periphery of Shanghaispelled the end of the mills as viable economic enterprises. The yarn and cloth that they once shipped around the region and even globally was no longer competitive under liberalising price measures and labour policies that permitted new rivals to emerge. A massive strike in Bombay in 1981-1982 mobilised the entire workforce of 250,000 mill workers, but mill owners had no reason to concede to their demands when the long-term strategy was to repurpose the mills and the land on which they were built. In Shanghai, as the first auctions for urban land got underway in the late 1980s, it was readily apparent to the textile bureaus and their officials that they too could repurpose the land on which the mills sat and make windfall revenues from the issuance of long-term leases to commercial real estate developers.

\section{Mills to Malls}

If $19^{\text {th }}$ century industrial capitalism under British domination brought about the creation of the mill districts of Shanghai and Bombay, $21^{\text {st }}$ century financial capitalism, in the form of real estate developers, sped the transformation of the mill districts into repurposed entertainment and high-end residential zones. Where my account departs from the more general view of neoliberal transformations of urban space found in the work of David Harvey and others is the importance of urban heritage and institutions and their ability to inflect and limit the capacity of capital to transform urban space at will (Harvey 2008, Smith 2002). In both cities, the transformation of mill districts was fragmented and partial, slowed or stymied by the inability of authorities to relocate the hundreds of thousands of mill workers' families from neighbourhoods. 'Accumulation by dispossession' was blocked by the practical problem of where to put people whose housing was being dispossessed. For residents of informal settlements (slums in Bombay, urban villages in Shanghai) dispossession was relatively easier, given that the residents had few if any legal claims to demand compensation. Textile workers (generally retired, and their relatives) were another matter.

In Bombay, the heritage of mill districts (specifically the mill compounds) fueled a controversy over who had legitimate claim to the land if it were to be commodified and repurposed for commercial uses. The mill compounds sat on land zoned for industrial use, since the colonial authorities in the 1850s and 1860s had designated the land for textile mill companies to rent. The rents were largely nominal. But if the mill owners were long term leaseholders, this did not give them full property rights to sell the land to developers. In Shanghai (which had a large share of urban land occupied by industrial work units in the 1980s and early 1990s), the mill managers and the industrial bureaus could more readily convert state-owned urban land to long-term leases to property development corporations. Far more complicated, in both cities, was how to move worker families from their residences, which generally were nearby but not directly on the site of the 
Figure 6 Parel District, Mumbai, 2017. Mill land under transformation to high-end commercial and residential properties (Source: the author).

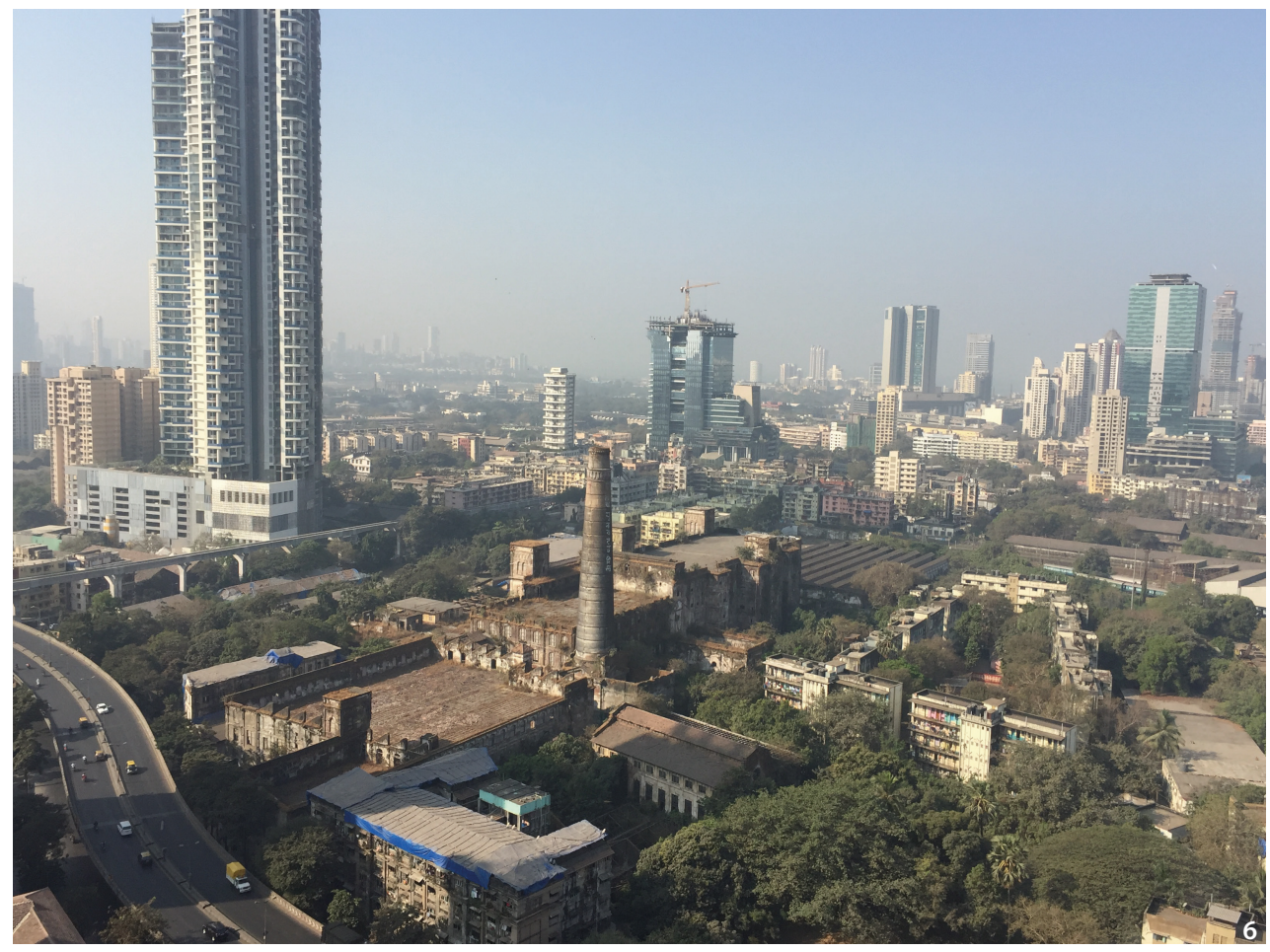

mill land. The institution of urban land ownership in both cities-owned by the state but leased to companies, and situated alongside high densities of working class families-produced a kind of hybrid landscape in the $21^{\text {st }}$ century: simply put, high-end real estate development (malls, hotels, office towers) sprang up in piecemeal fashion on some of the mill land, while worker residences were much slower and more likely to remain, given the pace at which city authorities could implement policies and schemes to relocate them.

Bombay's central mill districts, located on about 240 ha of land that could fetch some of the highest property prices in the city, were the subject of heated disputes in the 1990s. The land was zoned as industrial, and was subject to planning ordinances dating to the 1960s. New Development Control Regulations in 1991 liberalised land-use rules for the mill lands, and allocated a onethird allocation as follows: one-third of the land could be set aside for desperately needed public open space, onethird for affordable housing, and the remaining one-third could be converted to commercial and residential highend real estate projects. Over the next decade, disputes arose over precisely which parts of the mill land could be so allocated (the entire tract or only the unbuilt portions). Mill owners emerged victorious after court rulings that allowed for only the unbuilt portions to be allocated for affordable housing and public open space. And they could also repurpose existing built structures. Mill workers won a victory by being able to claim a substantial share of the affordable housing units, and to receive the units free of charge as compensation for the loss of jobs and livelihoods in the textile sector. The Mumbai Heritage Conservation Committee, formed in 1995, designated three categories of historic sites as eligible for preservation. Among the third category were several buildings in the mill district, but developers and some mill owners were able to effectively lobby the state government to remove these from protected status (Chalana 2012, 10). The most famous of these is the Phoenix Mill (built in 1905 under a different name), which became the High Street Phoenix luxury mall in 2000. In a gesture to preservation, the chimney from the Phoenix Mill remains, standing adjacent to the mall. On other mill land, five-star hotels as well as soaring office towers have been constructed or are being planned (Chalana 2012, 29) (Figure 6).

Shanghai's historic textile districts are also rapidly transforming, though they are not as centrally located to the city centre as are the mills in Mumbai. In Yangpu District, the old textile neighbourhoods of Gaolangqiao and Dinghaiqiao have retained a built heritage in spite of the official efforts by the district government to transform the area. In large part, the mill lands have been converted to commercial and residential housing, while the land on which the textile workers' housing sits retains much of the original residential structures. The area north of Changyang Road divides the site of the original Number 31 


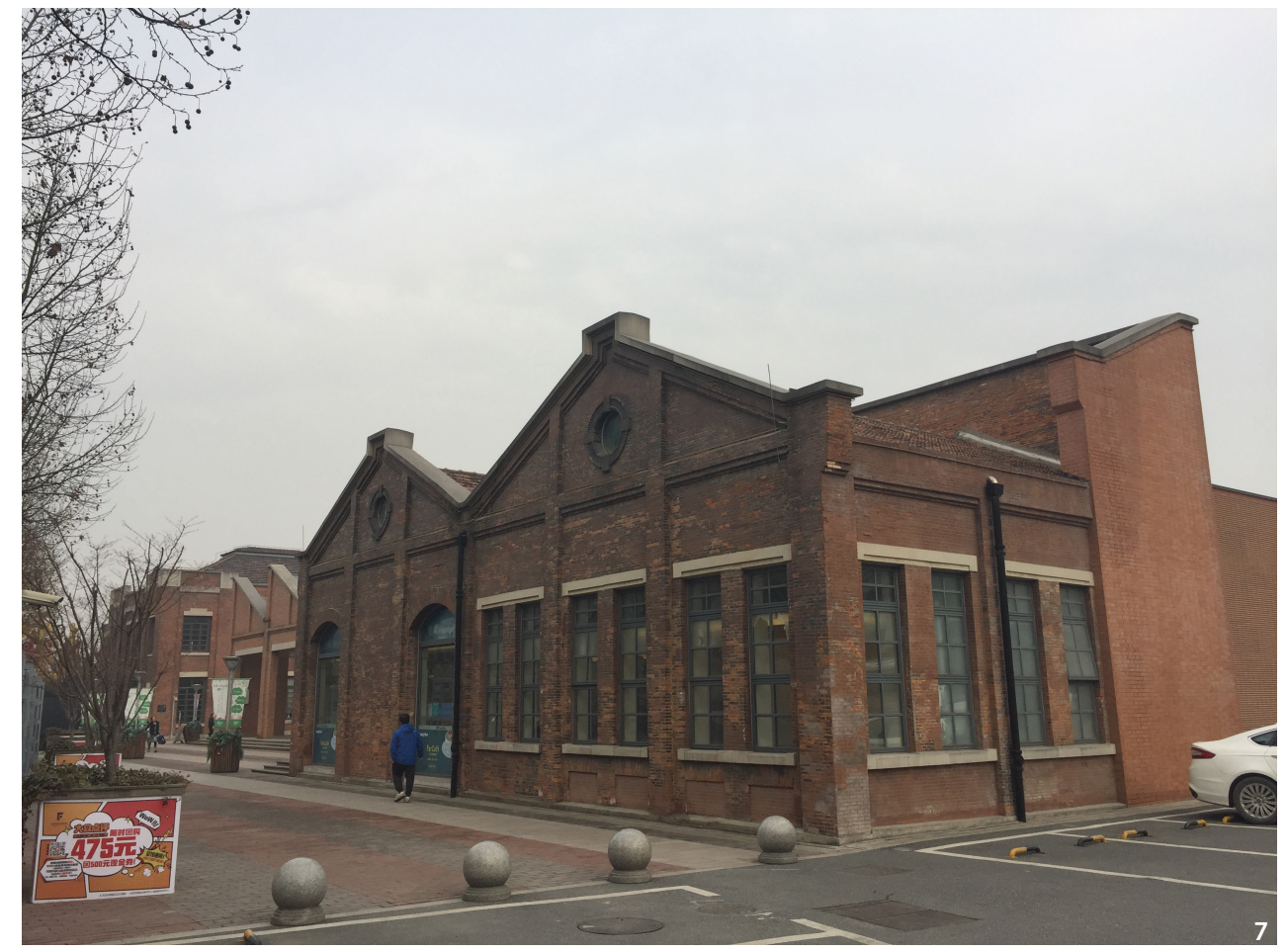

Figure 7 Shanghai International Fashion Centre, Yangpu District, 2018 (Source: the author).
Cotton Mill from the residential dwellings of its former workers. During the 1990s, mill management resolved debt burdens (a problem faced by most state-owned enterprises at the time) first by transferring just over 14,000 $\mathrm{m}^{2}$ of land-use rights to a real estate subsidiary of China Communications Bank, and then in 1996 transferring $71,000 \mathrm{~m}^{2}$ to the real estate subsidiary of China Construction Bank (Luo 2011, 457, 459). When the mill ceased all production the next year, the managers of Number 31 partnered with the Construction Bank real estate subsidiary to set up its own real estate development on the south side of Changyang Road (the site of the former mill) that sold commercial housing in two development projects (of $144,000 \mathrm{~m}^{2}$ combined) (Luo 2011, 460). Meanwhile on the north side of Changyang Road, walking from lane to lane in the neighbourhood north of the original mill, one can encounter rows of residential structures across the decades. From the 1930s to the 1990s, new housing units for textile workers were constructed from one block to the next, and the age of the units largely reflects the degree of dilapidation. Far from resisting resettlement, the central grievance among residents is that the government can no longer offer a properly valued compensation package to relocate them ${ }^{5}$. The land on which the residents rent or own their small units is simply too expensive for officials to offer payouts in large numbers. At the former site of the Number 17 Cotton Mill (where the Gang of Four member Wang Hongwen once worked before he was elevated to the central party leadership in 1973), a commercial shopping venue known in English as the Shanghai International Fashion Centre now stands on the banks of the Huangpu River (Figure 7). The former mill areas in Putuo District on the southern banks of Suzhou Creek are home to trendy arts districts such as 'M50'. Not far from M50, the Gu Zhenghong Memorial Hall honours the textile worker whose death at the hands of a Japanese security detachment at a Naigai Wata Mill in May 1925 sparked protests against the Shanghai Municipal Council that culminated in the May Thirtieth massacre of 13 students by British-led police and the ensuing general strike that summer.

In both cities, the commodification of land and repurposing of the mill districts resulted in developers and builders, along with the municipal authorities, making landfall profits. Yet the districts and their heritage did not disappear with the arrival of real estate developers. Workers and their neighbourhoods were victims, but some gained partial compensation in the form of relocation housing. In both Bombay and Shanghai, 'worker relocation housing' has become a prominent urban form produced from the transformation of the mill districts. Critical in both cities was a scheme to erase the property-less connotation of the 'proletariat' by according them with property in the form of apartments whose market value served as an ineluctable enticement to relocate from their old residences in the mill neighbourhoods. The financing 
in both cases came from the sale of mill lands-the Maharashtra Housing and Area Development Authority built the high-rise dwellings by receiving a one-third share of the sales proceeds of mill land. In Ghodapdeo, a parcel of land on the former site of a mill, 24-storey buildings housing former mill workers in 2017 were worth in property value 10 times what they were when the residents moved in 2011. The district governments in Shanghai who made deals with the textile bureau agencies and managers of individual mills invested some of the proceeds into large building compounds in the far reaches of the city, in districts such as Pudong and Baoshan. Sanlin Town in Pudong and Gucun in Baoshan inhabit vast stretches of former farmland from which now rise 24- to 30-storey residential towers housing hundreds of thousands of workers. Future students of urban heritage are likely to look back on worker relocation housing as a central feature of the built environment of the first decades of the $21^{\text {st }}$ century. But as for the original mill districts, only traces remain of the mill compounds, a few of which might at best be converted to museums or spaces like the Shanghai International Fashion Centre (which largely markets name brand apparel akin to a discount warehouse in the United States). Even the workers' new village housing that was the envy of all of Yangpu District residents now lies behind a walled compound, with the housing in a rapidly dilapidated condition, and the grounds giving way to weeds and wild shrubs.

\section{Conclusion}

Bombay's cotton mills-and more broadly, the Bombaybased trading companies exporting yarn, raw cotton, and opium to the newly-opened treaty port of Shanghai after 1844-helped finance the building of Shanghai in the second half of the $19^{\text {th }}$ century and its cotton textiles sector in the 1890s. The vector of influence had reversed by the late $20^{\text {th }}$ and early $21^{\text {st }}$ centuries, when Mumbai's civic leaders and the Indian government looked to Shanghai as a model for rapid urban development. McKinsey and Company produced a report in 2003 for the civic organisation known as Bombay First. Titled 'Vision Mumbai: Transforming Mumbai into a World Class City', the report heaped praise on Shanghai as a city that transformed itself through infrastructure-led development, from an 'unpainted wreck to a world-class city' (McKinsey and Company 2003, 10-11). The report drew a great deal of attention from both boosters and critics. Even the Indian prime minister at the time, Manmohan Singh, weighed in with the widely repeated remark that, 'When we talk of a resurgent Asia, people think of the great changes that have come about in Shanghai. I share this aspiration to transform Mumbai in the next five years in such a manner that people would forget about Shanghai and Mumbai will become a talking point' (Srivastava 2005). Singh's comments came just a few months after Mumbai authorities had engaged in the largest wave of slum demolition on record, with an eviction drive that razed settlements where an estimated 400,000 to 450,000 people $(94,000$ households) resided, at 44 different sites (Mahadevia and Narayanan 2008, 563-564). Critics of the Mumbai government dubbed the campaign 'Operation Shanghai', evoking the forceful relocation practices of the Shanghai government. These practices were admired among elite circles in India. However, in a tribute to the political heritage of the textile districts and families who had worked in the industry, in neither city could authorities infringe on the dwellings of the former textile workers without offering a substantial compensation in the form of ownership of a newly built apartment. The political struggles for citizenship by the textile workers of Shanghai and Bombay over the past century were in a direct sense concretised in the form of a modest (yet valuable in market terms) dwelling provided by the government. Workers who were once property-less had become small property owners, facing the risks and expenses that come with home ownership.

This discussion of the mill districts as sites of built heritage also suggests a more nuanced and contextualised understanding of the global process of gentrification and housing dispossession. Several of the most widely-cited urban theorists have made casual observations regarding such processes under way in $21^{\text {st }}$ century Mumbai and Shanghai. In a 2008 essay, Harvey cited the examples of the mass relocation of slum residents in Mumbai in 2004-2005 and the ongoing relocation of urban residents in China as examples of his concept of 'accumulation by dispossession' (Harvey 2008, 34-36). Neil Smith (2008, 196) noted that gentrification was 'happening on a more massive scale in Shanghai or Mumbai' than in the post-industrial cities of North American and Europe $(2008,196)$. In Shanghai and in Mumbai, global discourses of 'creative industry clusters' have resulted in the siting of various artistic and technology start-up spaces within repurposed industrial plants. The concept of industrial heritage tourism has also emerged, most prominently in spaces such as M50 in Shanghai (located in a former cotton mill on Suzhou Creek) and 798 in Beijing. Few would dispute that these broader processes of neoliberal development constitute a global theme with local variations, but paying 
attention to the latter-not simply the local but also the longer-term trends in local built heritage-can help illuminate the causes of these variations. Who gets dispossessed entirely, who gets dispossessed with partial compensation, and who remains exempt from dispossession are questions that reflect, as this article has shown, past patterns of citizenship and resulting claims to urban space and homestead. The mills and the mill districts may have disappeared or become gentrified consumption spaces, but the political heritage remains as residents lay claim to the prosperity that the textile sector once produced in Shanghai and Mumbai.

\section{Notes}

1. One dan equals 50 kilograms.

2. For more detail on mid-century Shanghai and Bombay, including the textile districts, see Frazier 2019.

3. This division between full-time and temporary workers was still an improvement over working conditions during the first half of the $20^{\text {th }}$ century, when even regular full-time mill workers in both cities could suddenly face unemployment for reasons ranging from the economic (e.g., declining profits) to the arbitrary and personal (e.g., dispute with one's shop floor boss).

4. Further specifics on labour policy in the two cities can be found in Frazier 2018.

5. Observations from site visits in January 2017, January 2018, April 2019.

\section{References}

Adarkar, Neera, and Meena Menon. 2004. One Hundred Years, One Hundred Voices: The Millworkers of Girangaon: An Oral History. Calcutta: Seagull Books.

Chalana, Manish. 2012. "Of Mills and Malls: The Future of Urban Industrial Heritage in Neoliberal Mumbai." Future Anterior 9 (1): 1-15.

Chandavarkar, Rajnarayan. 1994. The Origins of Industrial Capitalism in India: Business Strategies and the Working Classes in Bombay, 1900-1940. New York: Cambridge University Press.

Chandavarkar, Rajnarayan. 2009. History, Culture and the Indian City: Essays by Rajnarayan Chandavarkar. New York: Cambridge University Press.

Chen, Yingfang. 2007. "Kongjian yu shehui: zuowei shehui zhuyi shixian de chengshi gaizao: Shanghai penghuqu di shilie, 1949-1979" [Space and Society: Urban Transformation as Socialist Practice: The Case of Shanghai's Slum Settlements, 1949-1979.] Paper presented at
"Urban Flows-Rural Moves" Cultural Studies Research Conference, Taipei, January 6-7.

Chen, Zhilong. 2017. "Shanghai: A Window for Studying Sino-Indian Relations in the Era of Colonialism and Imperialism." In India and China in the Colonial World, edited by Madhavi Thampi, 33-54. New York: Routledge.

Dossal, Mariam. 2010. Theater of Conflict, City of Hope: Mumbai 1660 to Present Times. New York: Oxford University Press.

Farrer, James. 2019. "Grimy Heritage: Organic Bar Streets in Shanghai and Tokyo." Built Heritage 3 (3): 76-88.

Frazier, Mark W. 2018. "The Origins of State Capacity: Workers and Officials in Mid-20th Century Shanghai and Bombay." In Beyond Regimes: China and India Compared, edited by Prasenjit Duara and Elizabeth J. Perry, 33-54. Cambridge, MA: Harvard University Press.

Frazier, Mark W. 2019. The Power of Place: Contentious Politics in Twentieth Century Shanghai and Bombay. New York: Cambridge University Press.

Harvey, David. 2008. "The Right to the City." New Left Review, no. 53: 23-40.

Hazareesingh, Sandip. 2007. The Colonial City and the Challenge of Modernity: Urban Hegemonies and Civic Contestations in Bombay City, 1900-1925. Hyderabad: Orient Longman.

Holston, James. 2008. Insurgent Citizenship: Disjunctions of Democracy and Modernity in Brazil. Princeton, NJ: Princeton University Press.

Honig, Emily. 1986. Sisters and Strangers: Women in the Shanghai Cotton Mills, 1919-1949. Stanford, CA: Stanford University Press.

Luo, Suwen. 2011. Gaolangqiao jishi: jindai Shanghai yige mianfangzhi gongye qu de xingqi yu zhongjie [Records of Gaolangqiao: The Rise and the End of a Textile District in Modern Shanghai]. Shanghai: Shanghai renmin chubanshe.

Mahadevia, Darshini, and Harini Narayanan. 2008. "Shanghaing Mumbai: Politics of Evictions and Resistance in Slum Settlements." In Inside the Transforming Urban Asia: Processes, Policies, and Public Actions, edited by Darshini Mahadevia, 549-589. New Delhi: Concept Publishing Company.

McKinsey \& Company. 2003. "Vision Mumbai: Transforming Mumbai into a World-class City: A Summary of Recommendations." Mumbai: Bombay First and McKinsey \& Company.

Morris, David Morris. 1965. The Emergence of an 
Industrial Labor Force in India: A Study of the Bombay Cotton Mills, 1854-1947. Berkeley, CA: University of California Press.

Newman, Richard. 1981. Workers and Unions in Bombay, 1918-1929: A Study of Organization in the Cotton Mills. Canberra: Australian National University Monographs on South Asia.

Pearse, Arno S. 1929. The Cotton Industry of Japan and China. Manchester, England: International Federation of Master Cotton Spinners' and Manufacturers' Association.

Perry, Elizabeth J. 1993. Shanghai on Strike: The Politics of Chinese Labor. Stanford, CA: Stanford University Press.

Rutnagur, S. M. 1927. Bombay Industries: The Cotton Mills. Bombay: Indian Textile Journal, Ltd.

Smith, Neil. 2008. "On the Eviction of Critical Perspectives." International Journal of Urban and Regional Research 32 (1): 195-197.

Smith, S.A. 2002. Like Cattle and Horses: Nationalism and Labor in Shanghai, 1895-1927. Durham, NC: Duke University Press.

Srivastava, Siddharth. 2005. "Mumbai Struggles to Catch Up with Shanghai." Asia Times Online (March 16).

Upadhyay, Shashi Bhushan. 2004. Existence, Identity, and Mobilization: The Cotton Millworkers of Bombay, 18901919. New Delhi: Manohar Publishers. 